\title{
The competences of European Union institutions in the trade policy (Lisbon Treaty)
}

\author{
Margareta Tîmbur, „Al. I. Cuza” University of Iasi, Romania
}

\begin{abstract}
The European Union is the best known at the world's leading trade power and the common trade policy is the core of EU external relations. The events of the last years and the extension of the EU to 27 member proved that the functioning system could no longer continue and was requiring a new institutional framework. The Lisbon Treaty was the right solution. It purposes are to bring changes for the citizens, institutions, external relations foe the consolidation of democracy in EU.

This paper attempts to provide an overview of the major revisions introduced by the Treaty of Lisbon regarding the trade policy. Also, it analyses the extension and clarification of EU competence, the greater role of the European Parliament and the inclusion of investment policy in trade policy, the voting rules in trade area and the international negotiation of trade agreements. The study describes, as well, the impact of Lisbon Treaty implementation on the MS which are independent nations, but without power of decision in the common trade policy.
\end{abstract}

\section{Keywords}

common trade policy, European Union, intellectual property rights, Lisbon Treaty, foreign direct investments, trade agreements, Treaty establishing the European Community, Treaty of European Union, World Trade Organization.

JEL Codes: R11, R50, R58

\section{Introduction}

"Trade is one of the engines of growth" European Union countries are among the founders of modern international trade rules. This system has helped trade relations to run open, predictable and fairly. The European Union (EU) is facing new challenges that affect both, individual Member States (MS) and the EU as a whole. Economic globalization, demographic change, climate change, the need for sustainable energy sources, new security threats and global economic crisis are the current problems which require effective and urgent solutions at European level. This leads to a tight cooperation between MS in all areas, functioning as a whole with common purposes and objectives.

Thus, the EU is committed to pursue a trade policy that not only stimulates growth and creates jobs in Europe, but, also, can help countries and people worldwide to use actively trade as an instrument for development. Furthermore, the EU supports the rules of World Trade Organization (WTO), which provides a high degree of legal security and transparency in the world trade.

Trade was the first area where EU countries agreed to delegate some of its sovereignty and to transfer to the European Commission the responsibility to decide in trade relations, including the negotiation of international agreements. Consequently, the EU has a common trade policy (CTP) based on uniform rules. 


\section{The Lisbon Treaty}

„The Lisbon Treaty is not an end in itself, nor is it perfect. It is an improved set of rules to develop EU policy"

European Parliament President Jerzy Buzek

The Lisbon Treaty (LT) signed on December 13, 2007 and entered into force on December 1, 2009 , is a response with solutions for the listed above dilemmas, taking in account the social, economic and political changes, toward EU is currently undergoing. As a result of negotiations between the MS and the EU institutions, the Treaty strengthens the democratic and fundamental values of the Union in the form of new rules or amendments to previous rules under the Treaty of European Union (TEU) and the Treaty establishing the European Community (TEC). With regard to basic values, the LT raises the objective of trade integration to the priority level of the $\mathrm{EU}^{1}$.

As a whole field of regulation of international trade, the CTP is a policy with an intense dynamic. Until now, a short time ago, the issue to act with one voice in WTO, the question of the applicability of WTO rules and EU competence to sign multilateral trade agreements, were the main conflicting issues of the CTP. Today, when multilateralism is in crisis the challenge for the EU is to negotiate and sign international agreements with economic partnerships, which include rules on investment protection, and give unilateral responses to unfair trade practices ${ }^{2}$.

Lisbon Treaty extends the domain of trade policy implementation for including, also, the foreign direct investments (FDI) and the intellectual property (IP) instruments, such as trademarks, industrial designs and patents, copyrights, which are the drivers who trigger innovation, growth and competitiveness.

Before Lisbon, investments were considered an area of mixed competence, which meant that the EU and MS could maintain and adopt international investment agreements. For the first time, FDI are included in the scope of the CTP. After entry into force of the LT, EU will have exclusive competence in this area ${ }^{3}$. Accordingly, EU MS will not be able to conclude the so-called bilateral investment treaties (BITs) by themselves. Concerning the regulations of portfolio investments MS and EU will have a shared responsibility ${ }^{4}$.

Moreover, because the Lisbon Treaty doesn't specify whether the EU powers for FDI include both investment protection and liberalization, there may be some uncertainty about this. Currently, each EU country negotiates its own bilateral investment treaties containing safeguards investments, such as rules on the repatriation of funds and measures to protect against unlawful expropriation. The liberalization of investment regime (ex. reciprocity agreements on national treatment) is clearly within the exclusive competence of the EU. The extension of EU competence on FDI, has not limited only to the liberalization of investment regime, the Lisbon Treaty granted the powers and investment protection European Union. This could have negative consequences for BITs in force. EU exclusive competence in this area means that MS lose their competence to (re) negotiate, conclude and implement these investment treaties ${ }^{5}$.

\footnotetext{
${ }^{1}$ Koeb, E. 2008, A more political EU external action: Implications of the Treaty of Lisbon for the EU's relations with developing countries, ECDPM InBrief, 21, Maastricht, pp. 1-16

2 Bungenberg, M. (2009), Going Global? The EU Common Commercial Policy After Lisbon, European Yearbook of International Economic Law 2010, Springer Berlin Heidelberg, pp. 123-151

${ }^{3}$ Krajewski, M. (2005), External Trade Law and the Constitution Treaty: Towards a Federal and More Democratic Common Commercial Policy, Common Market Law Review, 42, Netherlands, pp. 91-127

${ }^{4}$ Ceyssens, J. (2005), Towards a Common Foreign Investment Policy? Foreign Investment in the European Constitution, Legal Issues of Economic Integration, Vol. 32, No. 3, Netherlands, pp. 259 291

${ }^{5}$ Leal-Arcas, R. (2007), Will EU MS Play Any Role at the WTO after the EU Reform Treaty?, Journal on International Constitutional Law, Vol. 2, Vienna, pp.75-90
} 
Innovation is an essential tool for maintaining competitiveness, growth and employment in the EU. This is why the Commission has identified investing in knowledge and innovation as one of the four key priorities. A strong system of intellectual property rights is a driving force for innovation, stimulating investment and facilitating the transfer of knowledge from the laboratory to the marketplace.

Three significant changes are made regarding voting rules in trade policy. Thus, the LT will simplify the existing provisions in earlier treaties. Qualified majority voting will be the general rule, but unanimity will apply when a trade agreement will contain provisions which unanimity is required for adoption of internal rules. Secondly, the qualified majority will not apply to commitments on cultural and audiovisual services risk prejudicing the EU's cultural and linguistic diversity; commitments on social, educational or health services risk seriously disturbing the national organization of such services and prejudicing the responsibility of MS to deliver them; and, where unanimity is required for the adoption of internal rules (article (art.) $188 \mathrm{C}, \mathrm{LT}$ ). The LT does not change in depth the CTP, but modernizes it by consolidating certain aspects, confirming that all key aspects of trade policy are the exclusive competence of the EU, including the international agreements on trade in services.

\section{The European Union institutions and its competences}

Since the European Economic Community (EEC) was set up in 1957, under Rome Treaty, trade policy was included in the category of common policies. In trade negotiations the EU acts as a single entity, and thus maximizes negotiating power through a very large weight had in all world trade. The fact that the EU actions in trade scope as a single entity does not neglect the any variety of interests of its members. The design of EU's trade policy is made in consultation with representatives of member countries and important decisions are taken even by the trade ministers of those countries. The European Parliament (EP), also involved in decision making, contributes to the legitimacy of those decisions.

The EU trade policy has as an objective to "encourage the integration of all countries into the world economy, including through the progressive abolition of restrictions on international trade" (art. 10A TEU). This objective is reinforced and expanded in art. 206 of the Treaty on the Functioning of the European Union (TFEU), which indicates that the EU, ,shall contribute to (...) the progressive abolition of restrictions on international trade and on foreign direct investment, and the lowering of customs and other barriers", and art. 133 (TEC) that says "common commercial policy is based on uniform principles, particularly with regard to tariff changes, tariff and trade agreements for uniform measures of liberalization, export policy and measures to protect trade including those taken in the event of dumping or subsidies."

This article allows for even greater liberalization: FDI and the "other" barriers are not mentioned in the original article. The latter expression refers to "non-tariff trade barriers" like environmental standards or consumer protections regulations, which are a target for the liberalization policies of, among others, the WTO.

Moreover, the CTP establishes common rules, including a common custom tariff, common import and export procedure, takes uniform measures to liberalize trade and establishes trade defense instruments. Trade policy involves all of us, every day, whatever we do and wherever we live. The trade development - if properly managed - is an opportunity for growth, and the key of EU economic development is to be competitive and to build the business on internationally agreed rules. According to TEC and TFEU the development decisions in the EU and institutional skills are the key elements of the CTP, leading to a clear division of political powers between EU and MS in any area of international trade negotiations. Thus, according to TEC and TEU, the trade with goods was within the exclusive competence of EU institutions, the investments - in the MS competences and some areas being subject of joint powers, national and EU. 
Regarding the CTP, there is a precise delimitation between functions and roles performed by main institution: Parliament, Commission, Council and MS.

\section{European Parliament}

At its origins, the role of the EP was very modest, as it possessed only consultative and supervisory powers, and was therefore formally excluded from the central decision-making process. ${ }^{6}$

The CTP authority was delegated to the Commission and Council and was not predicting formal involvement of Parliament in CTP Agreements. According TFEU, EP "acceptance" was required for major treaty ratifications, when referring to matters which go beyond trade. According to article 300 (TEC), Parliament has to give approval only on economic cooperation trade agreements and association agreements before they are concluded by the Council and implemented by the Commission. EP shared legislative power with Council. It had, therefore, the power to adopt European laws (directives, regulations, etc.). The codecision procedure was the ordinary legislative procedure, thus giving equal importance to Parliament and EU Council in a few areas (transport, environment and consumer protection). Two thirds of European laws were adopted jointly by the EP and Council; EP had an important responsibility to control the activities of the EU and it was regularly inviting the Commission and the Council to develop existing policies or to initiate new ones. EP was actively participating in debates on globalization. It was closely supervising the works of WTO. Also, it was giving his opinion on the outcome of EU negotiations in the WTO, through recommendations to the Commission, requesting creation of a parliamentary assembly attached WTO to enable every citizen to understand the mechanisms of WTO and its decisions. In accordance with the LT, the power of EP increased, getting the co-decision power with the Council at the same level. In addition, all trade agreements will be approved by Parliament, which will be informed of the progress of negotiations on those agreements. What does this mean?

- EU's international policies will become more predictable and have more weight on international scene;

- Greater involvement of EP in negotiating trade agreements will allow public participation in the ratification process and will create greater transparency.

Thus, the European Parliament:

-will ratify all trade agreements;

-will have greater powers by extending and strengthening the co-decision mechanism;

-will have the status of co-legislator of the Council (MS), which improves the democratic legitimacy of the EU in an important policy;

- will adopt, with the Council, the legislation regarding the implementation of CTP.

This makes the EP and Council to be equal in terms of making decisions in trade policy area. In terms of legislation, this means that Parliament should be co-legislator for reviewing antidumping rules or regulations based on the GSP. However, the improvement is partly or fully compensated by the fact that national parliaments lose their right to ratify trade agreements and therefore influence external trade policy.

Very important role has International Trade Commission (INTA) of the EP, which is responsible for defining and implementing the Union's CTP and foreign economic relations, in particular:

-financial, economic and commercial relations with third countries and regional organizations;

${ }^{6}$ Leal-Arcas, R. (2008), 50 Years of Trade Policy: Good Enough or as Good as It Gets?, Irish Journal of European Law, 15 (No.1 and 2), First LawLTD, UK, pp. 157-182 
-harmonization measures and technical standards in the areas covered by international legal instruments;

-relationships with relevant international organizations and organizations which promote the regional economic and commercial integration outside of the UE;

-relations with WTO, including its parliamentary dimension.

\section{European Commission}

In the negotiating process of CTP issues, European Commission is the negotiator representing all MS. To ensure implementation of the CTP measures, the European Commission, according to TEC and TFEU, recommends to MS the most appropriate methods of cooperation between them in order to avoid the emergence of economic difficulties for some of them and authorizes the adoption of national protection measures, setting out in these cases, proper terms and conditions for its application. Treaties are mentioning that in emergency cases the MS may request the Commission authorization to take these measures, if they consider necessary to remedy the disparities created by the application of CTP, insuring that such measures do not significantly disrupt the functioning of the internal market.

In accordance with the TFEU, TEC and LT, European Commission:

- submits proposals for the implementation of common trade policy;

- submits recommendations to the Council, where must be negotiated agreements with one or more States or international organizations;

- recommends the ways which MS can contribute to the development of CTP;

- authorizes MS to adopt necessary protection measures;

- it is the sole negotiator - in the end of the negotiation process we have only one agreement instead of 27 sets of commercial rules;

- represents the EU MS in the WTO - to speak with one voice;

- represents and defends European interests in the WTO judicial system;

- is responsible to ensure that the agreements negotiated are compatible with EU policies and rules;

- is responsible to ensure that imports entering into the European Union are traded at fair prices and do not harm to European companies and their workers;

- monitors and ensures the implementation of international agreements by using the WTO system and tools which promote and protect trade adopted by the EU;

- the officials from General Directorate for Trade from the European Commission are responsible for current negotiations and represent EU, as a whole, in Doha Round, regularly informing the Parliament;

- reports, to the Special Committee the progress of negotiations.

Regarding the decisional competences under LT, the European Commission, in addition to the powers and duties specified in previous treaties, will be required by law - as EU executive carrying out trade negotiations - to share information with Parliament Committee regarding international trade, the status and discussions with third countries. EP will be obliged to give its opinion on all international trade agreements, while the approving power remains in the hands of Council of Ministers. However EP approval seems to slow the whole process.

\section{Council}

Council holds the key of decision-making power, in terms of legislation and works largely on the principle of consensus, because the qualified majority creates the prerequisites for 
maintaining the trade policy as a "hostage" of other matters subject to consensus rules, risking that trade policy to be subject of "indirectly veto"7.

TEC stipulated to the Council the right to decide by qualified majority the authorization of Commission to represent the Community in trade negotiations and to establish its own negotiating mandate in this area. Treaty of Amsterdam keeps unaltered this Community competence, covered by the art. 131-134 TEC. As such, CTP is based on uniform principles in terms of changes in tariffs, tariff and trade agreements conclusion, trade liberalization measures, export policy and measures for trade protection (in cases of dumping and subsidies).

Art. 300(3) (TEC) states: "The Council shall conclude agreements after consulting the EP, except for the agreements referred to art. 133 (3), including cases where the agreement covers a field for which the procedure referred to, in art. 251 [decision procedure] or that referred to in art. 252 [the procedure of cooperation] is required for the adoption of internal rules. The EP shall deliver its opinion within a time limit which the Council may lay down according to the urgency of the matter. In the absence of an opinion within that time limit, the Council may act." So, the Council:

- authorizes the Commission to open negotiations and to represent the EU on EU trade agreements with third countries or international organizations;

- has the responsibility to ensure compatibility between the negotiated agreements, the policies and the internal rules of UE;

- decides through regulations in accordance with the ordinary legislative procedure the common commercial policy;

- adopts measures defining the framework of implemented CTP;

- can not conclude an agreement if it includes provisions that go beyond the Community's internal powers, especially if it leads to harmonization of the laws or regulations of the MS in area in which this Treaty rules are out of such an harmonization;

- at the end of a Round, must approve the results,

- states trade policy guidelines based on which the Commission outlines and carries out its EU priorities;

- may issue directives at any time of negotiations;

- approves or rejects trade agreements negotiated by the Commission.

\section{EU Member States}

In 1994, the European Court of Justice established the following rules: regulation of foreign trade (in goods and services) is subject to the exclusive powers of EU institutions, MS are keeping the powers (together with the Commission) in matters related to trade and liberalization of production factors (non extern services, investments, employment, property rights etc). According to CTP, none State can unilaterally modify the rules and customs regulations or to sign tariff agreements with third countries. These powers assign exclusively to EU bodies ${ }^{8}$.

Before the entry into force of the LT, EU MS:

- were asking Commission the permission to take the necessary measures by themselves;

- were having the opportunity to intervene in the conduct of negotiations;

- were concluding with EU the trade agreements;

- were applying the commercial policy measures.

\footnotetext{
${ }^{7}$ Pelkman, (2001) apud Vass, A. (2004), Protecționismul european. Implicații pentru România, Ed. Economica, Bucureşti, pp. 17-20

${ }^{8}$ Vass, A. (2004), Protecționismul european. Implicații pentru România, Ed. Economica, Bucureşti, pp $17-20$
} 
Under LT, national parliaments will not conclude anymore agreements on FDI, besides that they do not involve other issues that may lead to joint agreements ${ }^{9}$. MS will lose the power to negotiate, conclude and implement such agreements and the Union will be responsible for negotiations or negotiations of new or old investment agreements.

The complexity of decision making process has emphasized and with the increasing role of NGOs involved in the CTP, as a means to promote specific interests. These interest groups, whose economic and financial strength, the persuasion power in legislative structures and adaptation flexibility may degenerate into strong sources to maintain or promote the protectionism in $\mathrm{EU}^{10}$.

\section{Critics and conclusions on Lisbon Treaty}

Coloured by neo-liberalism, from the principles its promotes to the policies it advocates, the LT is an extension of those of Maastricht and Amsterdam. The EU will remain a privileged space for the promotion of neo-liberal policies. However, the current functioning of the Union is marked by a profound democratic deficit with a confusion of powers whereby the Executive of the Union, the Commission, has legislative and judiciary powers and the Council, a legislative organ, is the assembly of national executives.

The main critics addressed to the LT as a whole and to the CTP in particular are the democratic deficit and lack of responsibility. The increased role of the EP, a body directly elected by the European citizens, is not seen as a sufficient guarantee. The decreasing participation of citizens in the EU elections over the years seems to show little interest and failure to mobilize ${ }^{11}$.

Many experts indicate that Parliament could try to exert greater influence on EU trade policy objectives in accordance with new rules, rather than simply to give its approval at the end of negotiations ${ }^{12}$.

The main innovation introduced by the LT was to specify the various types of competence that exist in the EU, therefore, the Lisbon Treaty improved some aspects of the current EU's CTP, but created new (unnecessary) problems.

The implication of the Union's exclusive competence in trade policy is the assurance of the unitary representation of interests within the WTO for the first time in the $\mathrm{EU}^{13}$. The proposed changes tend toward greater centralization of trade policy and toward reducing the MS' influence in trade policy.

The art. 24 states „The Union may conclude agreements with one or more States or international organizations." Coupled with the removal of the veto (unanimity) this means that the EU can now agree trade deals with for example the WTO without MS consent. Therefore, it would not seem plausible to exclude EU MS from ratifying future trade agreements. Hence, can be concluded that the EU is not yet ready to bypass its MS in all areas of trade regulation (notably trade issues related to immigration policy) and consequently EU MS will continue to be present in the WTO $^{14}$. Parliamentary approval to conduct trade negotiations will slow the whole process. As a result, instead of working

\footnotetext{
9 Bungenberg, M. (2009), Going Global? The EU Common Commercial Policy After Lisbon, European Yearbook of International Economic Law 2010, Springer Berlin Heidelberg, pp. 123-151

${ }^{10}$ Vass, A. (2004), Protecționismul european. Implicații pentru România, Ed. Economica, Bucureşti, pp 17-20

${ }^{1}$ Balan, G. (2008), The common commercial policy under the Lisbon Treaty, Advanced Issues of European Law, 6th session, Dubrovnik

${ }_{12}$ Bungenberg, M. (2008), The Common Commercial Policy, Lisbon Paper, presented at the Hebrew University Jerusalem

${ }^{13}$ Leal-Arcas, R. (2007), Will EU MS Play Any Role at the WTO after the EU Reform Treaty?, Journal on International Constitutional Law, Vol. 2, Vienna, pp.75-90

${ }^{14}$ Leal-Arcas, R. (2008), 50 Years of Trade Policy: Good Enough or as Good as It Gets?, Irish Journal of European Law, 15 (No.1 and 2), First LawLTD, UK, pp. 157-182
} 


\section{Studies and Scientific Researches - Economic Edition, no. 15, 2010}

together in the draft amendment to the rules of trade, Council and EP will have to agree on the components of new trade agreements ${ }^{15}$.

The main changes to the LT, compared with the Nice Treaty on the CTP are:

- as to the structure of the Treaty, the base of the CCP is Title II of the Part five of the TFEU- External Action by the Union (Art. 206 and 207);

- as to the distribution of competences within the EU institutions, the EP becomes a player;

- national parliaments do not play a role anymore in ratifying trade agreements, as all trade in goods, services, IP and the FDI is exclusive European competence the actual decision making process will be substantially the same;

- the European Parliament, which has no competence in CTP under the Nice Treaty is now taking action under the co-decision procedure and gives its assent;

- the qualified majority remains the voting rule in the Council, unanimity being required only in the mentioned cases;

- the international agreements in the field of transport continue to not be covered by the CTP ${ }^{16}$.

The Lisbon Treaty makes the Union's CTP more federal, but not necessarily more democratic. The necessity to implement an international agreement of the Union will nevertheless put political pressure on the MS to adopt the relevant legislation. The formal competence of the MS to implement an international agreement may in fact not leave the MS a large margin of discretion.

\section{Bibliography}

1. Archick, K., Mix, D. (2009), Policy Studies Journal, CPRS Report for USA Congress

2. Balan, G. (2008), Advanced Issues of European Law, 6th session, Dubrovnik

3. Bungenberg, M. (2009), European Yearbook of International Economic Law 2010, Springer Berlin Heidelberg

4. Ceyssens, J. (2005), Legal Issues of Economic Integration, Vol. 32, No. 3, Aspen Publishers, Inc., Netherlands

5. Koeb, E. 2008, ECDPM InBrief, No. 21, ECDPM, Maastricht

6. Krajewski, M. (2005), Common Market Law Review, No. 42, Kluwer Low International, Netherlands

7. Lavranos, N. (2009), American Society of International Law, ASIL Insight, Washington DC

8. Leal-Arcas, R. (2007), Florida journal of international law, University of Florida Levin College of Law

9. Leal-Arcas, R. (2007), Journal on International Constitutional Law, Vienna

10. Leal-Arcas, R. (2008), Irish Journal of European Law, First LawLTD, UK

11. Leal-Arcas, R. (2008), in Kierkegaard, S. (ed.), The Dynamics of Trade Law and Economics, IA of IT Lawyers

12. Mackie, J. Frederiksen, J and Rossini, C. (2004), ECDPM, Discussion Paper 51, ECDPM, Maastricht

13. Matthews, Duncan N. (2010), European Intellectual Property Review, No. 3, Queen Mary School of Law

14. Nugent, N. (1999), The Government and Politics of the European Union, Ed. 4, Dhuram: Duke University Press

15. Reichert, S., Jungblut, B. (2007), The Policy Studies Journal, Vol. 35, No. 3

16. Vass, A. (2004), Protecționismul european. Implicații pentru România, Ed. Economica, Bucureşti

17. Willis, A. (2009), EU Observer, at http://euobserver.com/9/29119

18. Woolcock, S. (2008), European Policy Analysis, Swedish Institute for European Policy Studies

19. * Official Journal of the European Union

\footnotetext{
${ }^{15}$ Willis, A. (2009), EU Treaty Implications for Trade Unclear, EU Observer, at www.euobserver.com

16 Balan, G. (2008), The common commercial policy under the Lisbon Treaty, Advanced Issues of European Law, 6th session, Dubrovnik
} 
20. * The Treaty establishing the European Community (Consolidated version)

21. * The Treaty of Lisbon

22. * Treaty on the Functioning of the European Union (Consolidated version)

23. * The Treaty of European Union (Consolidated version)

24. * WTO, (2008), "Annual session of the Parliamentary Conference"

25. http://ec.europa.eu/index_ro.htm

26. http://eur-lex.europa.eu/LexUriServ

27. http://europa.eu/lisbon_treaty/glance/democracy/index_en.htm

28. http://www.consilium.europa.eu/showPage.aspx?id=1\&lang=ro

29. http://www.europarl.europa.eu/news/public/default_ro.htm

30. http://www.wto.org/english/tratop_e/tratop_e.htm 